\title{
Efisiensi Fiskal Terhadap Pembangunan Ekonomi Propinsi Di Pulau Jawa (Tahun 2005-2009)
}

\author{
Diana Wijayanti* \\ Ai Susan**
}

\begin{abstract}
The study was conducted to determine the extent to which fiscal policy can affect the efficiency of the economic development of each province on the island of Java. Data in this study sourced from a central bureau of statistics. Each province has different characteristics from one another. The difference of these characteristics is seen from the inputs used by each province of the output produced. This can be measured by using Indirect Expenditure report, Expenditures and direct Local Spending source as input variables. GDP or the rate of economic growth and employment as an output variable.

Analysis tools used in this study is the efficiency measurement model with technique Data Envelopment Analysis (DEA). DEA is a technique that compares linear programming of various inputs and output of each unit of economic activity (UKE).

This study concluded that: (1) Province in Java that can reach and be able to maintain a level of efficiency of 100\% from the year 20052009 only one province of East Java Province, while the Province of DKI Jakarta, West Java, Central Java, Yogyakarta and Bantam efficiency levels fluctuate each year. (2) Provinces that have a value of inefficient or $<100 \%$, occurred because the thriftless in the province of using the input.
\end{abstract}

Keywords: fiscal policy, efficiency, GDP .

\section{Pendahuluan}

Banyak teori dan studi yang menjelaskan bahwa pertumbuhan ekonomi dipengaruhi oleh modal fisik dan modal manusia serta teknologi (Todaro, 2000). Namun, meningkatnya studi ekonomi memperlihatkan wilayah diskusi yang jauh lebih luas. Beberapa studi mutakhir telah melangkah lebih jauh ke tema produktivitas pembangunan, infrastruktur publik dan hubungannya dengan investasi swasta serta implikasinya pada pertumbuhan ekonomi. Robert Baro (1991) memasukan pengeluaran pemerintah kedalam persamaan sebagai variabel

* Dosen Fakultas Ekonomi UII

* Alumni Fakultas Ekonomi UII 
endogen, mengasumsikan bahwa pengeluaran pemerintah sebagai variabel flow, ternyata memberikan efek yang positif terhadap pertumbuhan ekonomi.

Greiner (1996) menemukan bahwa pengeluaran pemerintah produktif meningkatkan produk marginal dari modal swasta dan akan menghasilkan pertumbuhan perkapita terus-menerus.

Temuan lain yang menarik diberikan oleh Miller dan Russek (1997). Mereka membuktikan bahwa pajak-pajak daerah dan negara merugikan pertumbuhan ekonomi jika penerimaannya untuk membiayai transfer payment, tetapi tidak merugikan jika pembiayaan jasa-jasa publik. Sedangkan M'Amanja \& Morrissey (2006), dalam penelitian mereka di Kenya tahun untuk kurun 1964-2002, menunjukkaan bahwa pengeluaran pemerintah produktif berpengaruh kuat terhadap pertumbuhan ekonomi. Di sisi lain investasi pemerintah memberikan kontribusi jangka panjang terhadap pertumbuhan ekonomi.

Beberapa studi lain menyebutkan pengenaan pajak akan menurunkan pertumbuhan ekonomi negara, jika penerimaannya digunakan untuk membiayai pendidikan, transportasi dan keamanan publik. Kajian terhadap 41 literatur studi dampak kebijakan fiskal terhadap pertumbuhan ekonomi yang dilakukan Nijkamp dan Poot (2002) menemukan 29 persen sampel studi mengindikasikan hubungan negatif antara kebijakan fiskal dengan pertumbuhan ekonomi, 17 persen lainnya menyebutkan hubungan yang positif. Sedangkan 54 persen sisanya tidak memberikan kesimpulan meyakinkan tentang dampak positif kebijakan fiskal terhadap pertumbuhan ekonomi.

Sampai di sini terlihat bahwa teori pertumbuhan berbasis modal fisik dan pengeluaran fiskal pemerintah masih bergerak antara pembuktian dan penyangkalan. Meskipun begitu, teori tersebut memiliki konvergensi yang sangat mencolok dengan teori efisiensi fiskal yang mendorong gelombang desentralisasi di banyak negara, termasuk Indonesia.

Desentralisasi secara radikal di Indonesia sejak tahun 2001, tidak hanya dilatarbelakangi oleh kegagalan perencanaan terpusat dan populernya strategi pembangunan pemerataan (growth with equity), tetapi dengan desentralisasi proses pembangunan akan berjalan lebih efisien, daerah diberikan kewenangan untuk menyelenggarakan program-program pembangunan, sehingga seluruh pertanggungJawaban pengelolaan dan pembiayaan dilakukan oleh pemerintah daerah. Perubahan tersebut menuntut daerah untuk melihat kembali dampak aktivitas pemerintah daerah dan swasta terhadap ekonomi daerah.

Hal ini akan memberikan dampak positif terhadap pertumbuhan ekonomi daerah. Ding, 2002 melakukan penelitian di Cina, pada tahun 1994-2002 dan menemukan bahwa desentralisasi fiskal mempunyai dampak positif terhadap pertumbuahn ekonomi dan terbukti meningkatkan efisiensi ekonomi Cina. 
Studi Martinez-Vazquez (2001) menyebutkan bahwa desentralisasi fiskal mempengaruhi pertumbuhan ekonomi melalui efisiensi ekonomi, distribusi regional, dan stabilisasi ekonomi makro.

Jika desentralisasi diletakkan di atas asumsi maksimisasi kesejahteraan, maka kebijakan fiskal pemerintahan daerah dapat diperlakukan sebagai instrumen yang memungkinkan investasi tumbuh. Pada saat yang sama, kebijakan fiskal dan keuangan daerah dapat memainkan peran sebagai sistem insentif investasi 'dan mendorong pertumbuhan ekonomi. Meskipun demikian, implikasi kebijakan fiskal terhadap pertumbuhan ekonomi masih banyak diperdebatkan baik dari segi teori maupun studi empiris masih terus berkembang. Bahkan perkembangan studi tidak hanya mencakup dari sisi kuantitasnya saja, namun berkembang pada sejauh mana efisiensi dan efektifitas kebijakan fiskal terhadap pertumbuban ekonomi.

Pulau Jawa merupakan pulau yang memiliki jumlah kepadatan penduduk yang tinggi, pusat aktifitas ekonomi banyak terdapat di pulau Jawa khususnya di DKI Jakarta. Pemberlakuan desentralisasi fiskal semakin meningkatkan kemajuan berbagai propinsi di pulau tersebut. Pertumbuhan ekonomi di Pulau Jawa setiap tahunnya mengalami kenaikan yang cukup tinggi, dapat dilihat dari tabel (Produk Domestik Regional Bruto) PDRB di bawah ini.

Tabel 1

Produk Domestik Regional Bruto (PDRB) dan Kesempatan Kerja di Pulau Jawa tahun 2005-2009

(Dalam Rupiah)

\begin{tabular}{|c|c|c|}
\hline Tahun & 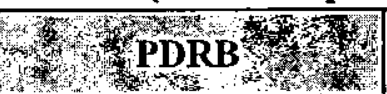 & Kesempatan Kerja \\
\hline 2005 & 1.012 .666 & 56.484 .071 \\
\hline 2006 & $1.071 .135,5$ & 57.033 .546 \\
\hline 2007 & $1.137 .414,4$ & 59.910 .151 \\
\hline 2008 & 1.204 .499 & 58.687 .191 \\
\hline 2009 & $1.262 .007,3$ & 61.760 .684 \\
\hline
\end{tabular}

Sumber Data: BPS “ Statistik Keuangan Daerah Provinsi “

Untuk memperkaya khasanah ilmu, penelitian ini bermaksud mengukur sejauh mana efisiensi fiskal dapat mempengaruhi pembangunan ekonomi tiap propinsi di Pulau Jawa. 


\section{Kajian Pustaka}

Ada beberapa studi terdahulu yang dilakukan mengenai peranan sektor publik lokal terhadap pertumbuhan ekonomi regional. Diantaranya oleh Kim (1997) yang melakukan penelitian di Korea. Hasil penelitian tersebut adalah bahwa peranan sektor publik lokal selama periode 1970-1991 mempunyai pengaruh yang signifikan terhadap pertumbuhan ekonomi di Korea. Diantaranya adalah bahwa pajak lokal (daerah) dan penerimaan non pajak mempunyai pengruh negatif yang signifikan terhadap pertumbuhan ekonomi, sementara investasi dan konsumsi pemerintah daerah mempunyai pengaruh positif yang kuat dan signifikan.

Berlawanan dengan Kim, temuan Rahayu (2000) yang melakukan penelitian di Indonesia tahun 1987-1996, menyimpulkan bahwa pajak lokal dan penerimaan non pajak mempunyai pengaruh yang signnifikan secara positif terhadap pertumbuhan ekonomi regional. Sementara Investasi pemerintah daerah mempunyai efek signifikan yang negatif terhadap pertumbuhan ekonomi regional. Studi dari Helms (1985) dengan menggunakan panel data menemukan bahwa kenaikan dalam pajak total dan pajak negara bagian (state) secara signifikan memperlambat pertumbuhan ekonomi ketika penerimaannya digunakan untuk membiayai transfer. Akan tetapi ketika penerimaan digunakan untuk membiayai pemeliharaan dan pengembangan jasa-jasa publik, pajak lokal mempunyai pengaruh yang menguntungkan bagi ekonomi regional.

Ding, (2002) melakukan penelitian di Cina, pada tahun 1994-2002 dan menemukan bahwa desentralisasi fiskal mempunyai dampak positif terhadap pertumbuhan ekonomi dan terbukti meningkatkan efisiensi ekonomi Cina. Studi Martinez-Vazquez, (2001) menyebutkan bahwa desentralisasi fiskal mempengaruhi pertumbuhan ekonomi melalui efisiensi ekonomi, distribusi regional, dan stabilitas ekonomi makro.

Afonso Antonio, Ludger Schuknecht dan Vito Tanzi (2003), melakukan studi tentang efisiensi sektor publik di 23 negara industri. Efisiensi dilihat dari rasio antara kinerja sektor publik dengan belanja sektor publik, dengan menggunakan total pengeluaran pemerintah sebagai proksi dari penggunaan sumberdaya. Mereka menemukan bahwa negara dengan pengeluaran sektor publik yang lebih rendah memberikan kinerja ekonomi yang lebih baik. Sedangkan negara dengan pengeluaran sektor publik yang lebih besar menunjukkan distribusi pendapatan yang lebih merata. Pengeluaran sektor publik yang berbeda menghasilkan tingkat efisiensi yang berbeda. Negara dengan pengeluaran sektor publik lebih rendah mempunyai efisiensi yang lebih tinggi dibandingkan negara yang pengeluaran sektor publiknya lebih besar. 


\section{Landasan Teori}

\section{Efek Kebijakan Fiskal dalam Menentukan Output Nasional}

Kebijakan fiskal, adalah kebijakan pemerintah dalam prekonomian dengan instrumen fiskal, yaitu pajak dan goverment expenditure. Kebijakan fiskal mencakup sisi penerimaan dan pengeluaraan dalam anggaran pemerintah. Menurut Keynes kebijakan fiskal akan berpengaruh pada permintaan agregat dan sejalan dengan yang dikembangkan oleh Musgrave (1980), bahwa tujuan kebijakan fiskal dapat digunakan untuk mencapai distribusi pendapatan (distribution), realokasi sumber daya (alocation) dan stabilisasi ekonomi (stabilization).

Output nasional ditentukan oleh interaksi antara Agregat Supply dan Agregat Demand. Pergeseran dalam Agregat Demand mengakibatkan pergeseran dalam output nasional dan demikian pula dengan employment, dengan kurva Agregat supply berslope positif, jika upah nominal tidak menyesuaikan dengan cepat untuk menjamin kondisi prekonomian dalam keadaan full employment di pasar tenaga kerja. Pemerintah melalui kebijakannya dapat mempengaruhi output dalam prekonomian.

Para ekonom, aliran Keynesian mengatakan bahwa pemerintah dapat menggunakan kebijakan makro ekonomi untuk menstabilkan prekonomian pada tingkat full employment melalui penyesuaian kebijakan fiskal. Kenaikan belanja pemerintah akan menyebabkan kenaikan yang lebih tinggi pada tingkat pendapatan.Menurut Keynes kebijakan fiskal akan berpengaruh pada permintaan agregat dan sejalan dengan yang dikembangkan oleh Musgrave (1980), bahwa tujuan kebijakan fiskal dapat digunakan untuk mencapai distribusi pendapatan (distribution), realokasi sumber daya (alocation) dan stabilisasi ekonomi (stabilization). Para ekonom, aliran Keynesian mengatakan bahwa pemerintah |dapat menggunakan kebijakan makro ekonomi untuk menstabilkan prekonomian pada tingkat full employment melalui penyesuaian kebijakan fiskal. Kenaikan belanja pemerintah akan menyebabkan kenaikan yang lebih tinggi pada tingkat pendapatan. 
Teori Klasik menjelaskan pemerintah mempunyai fungsi fiskal yang meliputi distribusi, stabilisasi dan alokasi (Musgrave, 1984) sebagaimana bagan berikut.

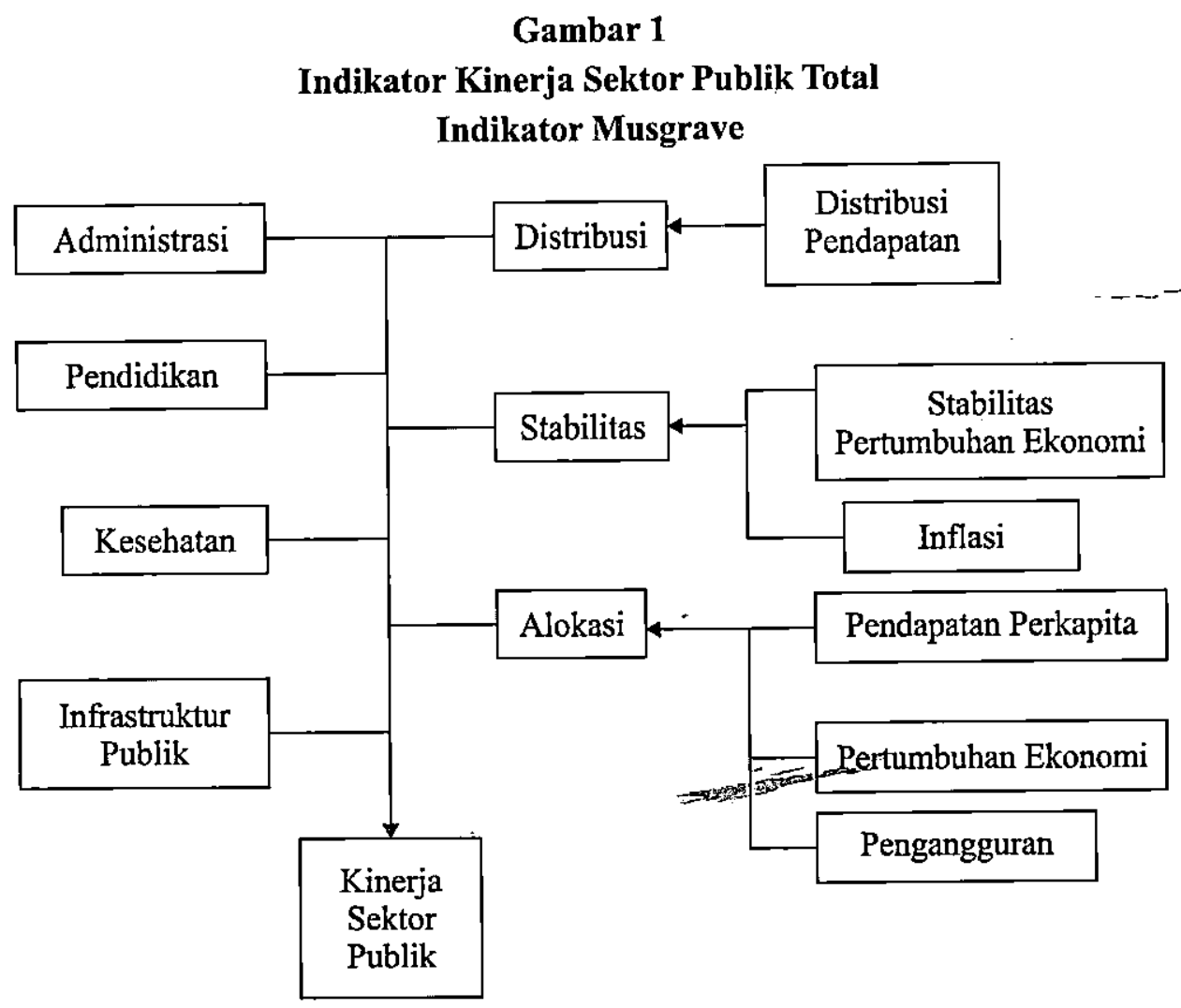

Peranan distribusi lebih banyak dilakukan oleh pemerintah pusat, karena pajak progresif ada di dalam pengelolaan pemerintah pusat, pemerintah daerah tidak memiliki kapasitas yang besar dalam perpajakan. (Brown and Jackson, 1990 , p. 48). Pemerintah daerah juga hanya mempunyai peranan kecil di dalam fungsi stabilisasi karena memerlukan kontrol pusat terhadap penawaran uang dan neraca pembayaran. (Bennett, 1980, p.11). Peranan pemerintah daerah lebih cenderung pada fungsi alokasi yang secara substansial menjelaskan bahwa fungsi alokasi akan lebih efisien dengan kebijakan desentralisasi (Smoke, 1994, p. 28).

\section{Tiebout Model}

\section{Efisiensi dalam Penyediaan Barang dan Jasa Publik Lokal}

Salah satu pertimbangan dari penerapan desentralisasi fiskal menurut persfektif kepentingan ekonomi adalah sebagai upaya menciptakan efisiensi dalam penyediaan barang dan jasa publik. Litvack et al (1998), mengutip 
argumen dalam penyediaan barang dan jasa publik. Litvack et al (1998), mengutip argumen yang dikemukakan oleh Tiebout (1956), Oates (1972), Tresch (1981), Weingast (1995) dan Breton (1996), menyatakan bahwa pelayanan publik yang paling efisien seharusnya diselenggarakan oleh wilayah yang memiliki kontrol geografis yang paling minimun, dengan alasan:

1. Pemerintah lokal sangat menghayati kebutuhan masyarakatnya.

2. Keputusan pemerintah lokal sangat responsif terhadap kebutuhan masyarakat sehingga mendorong pemerintah lokal untuk melakukan efisiensi dalam penggunaan dana yang berasal dari masyarakat.

3. Persaingan antar daerah dalam memberikan pelayanan kepada masyarakatnya akan mendorong pemerintah lokal untuk melakukan inovasinya.

Tiebout mengemukakan bahwa ada faktor yang terlupa dalam penyediaan barang dan jasa publik, yaitu pendanaan dan kompetensi. Pada pasar barang swasta, pendanaan merupakan pemicu yang paling mendasar mengenai efisiensi pasar barang swasta. Sedangkan kompetensi mendorong perusahaan-perusahaan untuk memproduksi barang swasta seefisien mungkin sehingga mereka dapat berkompetisi di pasar.

Jika penyediaan barang dan jasa publik diselenggarakan secara sentralisasi, akibatnya adalah ketiadaan/rendahnya kompetisi nyata yang dihadapi oleh pemerintah pusat pada saat pembuatan keputusan berkaitan dengan penyediaan barang dan jasa publik. Keputusan yang dihasilkan dapat tidak efisien sama sekali. Oleh karena itu, Tiebout menyarankan agar penyediaan barang dan jasa publik sebaiknya diselenggarakan oleh pemerintah daerah (local government). Tiebout berpendapat bahwa pada saat barang dan jasa publik disediakan di tingkat lokal, kompetisi antar pemerintah daerah secara natural akan meningkat karena individu yang menjadi penduduk suatu daerah dapat memilih dan menilai sendiri kualitas dari penyediaan barang dan jasa publik oleh suatu pemerintah daerah dibandingkan dengan kontribusi yang telah dibayarkannya dalam bentuk pajak daerah dan retribusi daerah.

Tiebout menekankan bahwa tingkat dan kombinasi pembiayaan barang dan jasa publik bertaraf lokal dan pajak yang dibayar oleh masyarakat merupakan kepentingan politisi, masyarakat lokal, dan pemerintah daerahnya. Masyarakat akan memilih untuk tinggal di lingkungan yang anggaran daerahnya memenuhi preferensi yang paling tinggi antara pelayanan publik dari pemerintah daerahnya dengan pajak yang dibayar oleh masyarakat.

Ketika masyarakat tidak senang pada kebijakan pemerintah lokal dalam pembebanan pajak untuk pembiayaan barang publik bersifat lokal, maka hanya ada dua pilihan bagi. warga masyarakat, yaitu meninggalkan wilayah tersebut atau tetap tinggal di wilayah tersebut dengan berusaha mengubah kebijakan 
pemerintah lokal melalui legislatif-nya (Hyman, 2003). Hipotesis tersebut memberikan petunjuk bahwa terdapat potensi untuk mencapai efisiensi ekonomi (maximizing social welfare) dalam penyediaan barang publik pada tingkat lokal.

Meskipun model Tiebout ini sangat menarik, terdapat sejumlah catatan berkenaan dengan permasalahan yang muncul dalam memprediksi model Tiebout mengenai penyediaan barang publik yang efisien, seperti masalah berkaitan dengan kompetensi antar pemda, masalah berkaitan dengan pendanaan, asumsi tidak adanya eksternalitas/spillover berkaitan dengan penyediaan barang/jasa publik lokal dan tidak adanya hambatan bagi mobilitas yang bersifat sempurna (Gruber, 2008). Setidaknya, model Tiebout ini mampu menunjukkan kondisi yang diperlukan untuk mencapai efisiensi ekonomi dalam penyediaan barang publik yang bersifat lokal yang pada gilirannya akan menciptakan kondisi yang dikenal sebagai "the market for local services would be perfectly competitive" (Tresch, 1981), (Aronson, 1985), dan (Stiglitz, 1988). (Sampurna Budi utama, 2011).

\section{Metode Penelitian}

\section{Data Penelitian}

Penelitian ini menggunakan lima variabel penelitian yang dibagi menjadi tiga variabel input dan dua variabel output. Analisis ini melibatkan 6 propinsi yang ada di Pulau Jawa yang mempunyai kapasitas berbeda-beda khususnya perbedaan kapasitas fiskal. Adapun variabel yang dikategorikan sebagai variabel input adalah :

1. Belanja Tidak Langsung

Variabel ini digunakan sebagai indikator kemampuan fiskal daerah yang mempunyai kontribusi penting dalam pembangunan

2. Belanja Langsung

Sebagai alokasi anggaran terbesar di daerah yang juga merupakan konsumsi pemerintah

3. Sumber Pengeluaran Daerah

Merupakan sumber dana yang dikeluarkan oleh Pemerintah Daerah yang akan mendorong pembangunan daerah.

Variabel output yang dipilih dalam penelitian ini adalah :

1. PDRB Riil

Variabel ini dipilih, karena PDRB merupakan besarnya output yang bisa dihasilkan oleh daerah. Hal ini menunjukkan tingkat produktivitas dan kemampuan daerah dalam pembangunan ekonominya. 
2. Jumlah penduduk yang bekerja sebagai proksi dari variabel pengangguran. Variabel ini dipilih karena keberhasilan daerah dalam menaikkan PDRB dapat berdampak pada penyerapan tenaga kerja sehingga mengurangi angka pengangguran.

\section{Alat Analisis}

Alat analisis yang digunakan dalam penelitian ini adalah teknik pengukuran efisiensi dengan model Data Envelopment Analyisis (DEA). DEA merupakan teknik programasi liniear yang membandingkan berbagai input dan output dari masing-masing unit kegiatan ekonomi (UKE) dan memilih unit-unit yang relatif efisien terhadap unit-unit lainnya. Jadi, masing-masing unit menjadi referensi bagi kinerja unit-unit lainnya.

Data Envelopment Analysis dapat mengatasi keterbatasan yang dimiliki analisis rasio persial dan regresi berganda. DEA merupakan prosedur yang dirancang secara kusus untuk mengukur efisiensi relatief suatu unit kegiatan ekonomi (UKE) yang menggunakan banyak input dan banyak output, dimana penggabungan input dan output tersebut tidak mungkin dilakukan. Efisiensi relatief suatu UKE adalah efisiensi suatu UKE dibanding dengan UKE lain dalam sampel (sekelompok UKE yang saling diperbandingkan) yang menggunakan jenis input dan output yang sama.

Dalam DEA, efisiensi relatif UKE didefinisikan sebagai rasio dari total output tertimbang dibagi total input tertimbangnya (total weighted output/total weighted input). Inti dari DEA adalah menentukan bobot (weighted) atau timbangan untuk setiap input dan output UKE. Bobot tersebut memiliki sifat yaitu tidak bernilai negatif, dan bersifat universal, artinya setiap UKE dalam sampel harus dapat menggunakan seperangkat bobot yang sama untuk mengevaluasi rasionya (total weighted output/ total weighted input) dan rasio tersebut tidak boleh lebih dari 1 (total weighted output/ total weighted input $\leq I$ ).

DEA berasumsi bahwa setiap UKE akan memiliki bobot yang memaksimumkan rasio efisiensinya (maximize total weighted output/total weighted input). Karena setiap UKE menggunakan kombinasi input yang berbeda untuk menghasilkan output yang berbeda pula, maka setiap UKE memiliki seperangkat bobot yang mencerminkan keragaman tersebut. Secara umum UKE akan menetapkan bobot yang tinggi untuk input yang penggunaanya sedikit dan untuk output yang dapat diproduksi dengan banyak. Bobot-bobot tersebut bukan merupakan nilai ekonomis dari input dan outputnya, melainkan sebagai penentu untuk memaksimumkan efisiensi dari suatu UKE.

DEA memiliki beberapa nilai manajerial. Pertama, DEA menghasilkan efisiensi untuk setiap UKE, relatif terhadap UKE yang lain didalam sampel. Kedua, 
jika suatu UKE kurang efisien (efisiensi $<100 \%$ ), DEA menunjukan sejumlah UKE yang memiliki efisiensi sempurna (efficient reference set, efisiensi $=100 \%$ ) dan seperangkat angka pengganda (multipliers) yang dapat digunakan oleh menejer untuk menyusun strategi perbaikan. Ketiga, DEA menyediakan metrik efisiensi silang. Efisiensi silang UKE A terhadap UKE B merupakan rasio dari output tertimbang dibagi input tertimbang yang dihitung dengan menggunakan tingkat input dan output UKE A dan bobot input dan output UKE B.

Penerapan program linear pada DEA. Misal, kita akan membandingkan efisiensi dari sejumlah UKE, misalkan $n$. setiap UKE menggunakan $m$ jenis input yang menghasilkan $s$ jenis output. Misal, $\mathrm{X}_{\mathrm{j} j}>0$ merupakan jumlah input $i$ yang digunakan oleh UKE $j$, dan misalkan $\mathrm{Y}_{\mathrm{rj}}>0$ merupakan jumlah output $r$ yang dihasilkan oleh UKE $j$. variabel keputusan (decision variables) dari kasus tersebut adalah bobot yang harus diberikan pada setiap input dan output oleh UKE $k$.

Misal Vik adalah bobot yang diberikan kepada input $i$ oleh UKE $k$, dan Urk adalah bobot yang diberikan pada output $r$ oleh UKE $k$. sehingga $V_{i k}$ dan Urk merupakan variabel keputusan, yaitu variabel yang nilainya akan ditentukan melalui iterasi program linear. Kemudian memformulasikan sejumlah $n$ program linear fraksional (fractional linear programs), suatu formulasi program linear untuk setiap UKE di dalam sampel. Fungsi tujuan (objective function) dari setiap program linear fraksional tersebut adalah rasio dari output tertimbang total (total weighted output) dari UKE $k$ dibagi dengan input tertimbang totalnya.

Formulasi fungsi tujuan tersebut adalah sebagai berikut :

$$
\text { Maksimumkan } Z_{k}=\frac{\sum_{r=1}^{s} U_{r k} \cdot Y_{r k}}{\sum_{i=1}^{m} V_{i k} \cdot X_{i k}}
$$

Kriteria universalitas menyatakan DMU $k$ untuk memilih bobot dengan batasan atau kendala bahwa tidak ada UKE lain yang akan memiliki efisiensi lebih besar dari 1 atau $100 \%$ jika UKE lain tersebut menggunakan bobot yang dipilih oleh UKE $k$.

Sehingga formulasi selanjutnya adalah :

$$
\frac{\sum_{r=1}^{s} U_{r k} \cdot Y_{r j}}{\sum_{i=1}^{m} V_{i k} \cdot X_{i j}} \leq 1 \quad ; j=1, \ldots, n
$$

Bobot yang dipilih tidak boleh bernilai negatif :

$$
\begin{aligned}
& U_{r k} \geq 0 ; r=1, \ldots, s \\
& V_{i k} \geq 0 ; r=1, \ldots, m
\end{aligned}
$$


Diana Wijayanti \& Ai Susan, Efisiensi Fiskal terhadap Pembangunan Ekonomi

Program linear fraksional kemudian ditransformasikan kedalam program linear biasa (ordinary linear program), dan metode simpleks dapat digunakan untuk menyelesaikanya. Transformasi program linear, yang disebut dengan DEA (data envelopment Analysis), adalah sebagai berikut :

$$
\text { (DEA)Maksimumkan } Z_{k}=\sum_{r=1}^{s} U_{r k} \cdot Y_{r k}
$$

Dengam batasan atau kendala :

$$
\begin{gathered}
{\left[P_{k j}\right] \quad \sum_{r=1}^{s} U_{r k} \cdot Y_{r j}-\sum_{i=1}^{m} V_{i k} \cdot X_{i j} \leq 0 ; j=1, \ldots, r} \\
{\left[q_{k}\right] \quad \sum_{i=1}^{m} V_{i k}, X_{i k}=1} \\
U_{r k} \geq 0 ; r=1, \ldots, s \\
V_{r i k} \geq 0 ; i=1, \ldots, m
\end{gathered}
$$

Metode DEA dikembangkan oleh Charnes, Cooper dan Rhodes (1978) untuk mengatasi kesulitan pengukuran efisiensi relative dengan keberadaan multiple input dan output. DEA memiliki beberapa kelebihan dan kelemahan dibandingkan dengan teknik pengukuran kenerja lainnya, kelebihannya antara lain:

a. Dapat mengidentifikasikan efisiensi dari berbagai unit kegiatan ekonomi (UKE) dengan berbagai variabel input dan output

b. Mampu mengidentifikasi sumber-sumber inefisiensi secara spesifik sehingga diperoleh informasi secara rinci pada masing-masing UKE

c. Dari hasil pertama dan kedua dapat disusun strategi pengembangan suatu UKE sehingga mencapai kinerja yang optimal

Adapun kelemahannya adalah:

a. Diperlukannya pemahaman yang mendalam terhadap variabel dan karakteristik UKE yang digunakan. Kesalahan peneliti dalam memahami karakteristik tersebut bisa berakibat pada kesalahan interprestasi.

b. Model DEA sangat sensitive terhadap nilai ekstrim 


\section{Analisis Data}

Pengukuran efisiensi berdasarkan pada programasi linier yang membandingkan input dan output. Penelitian ini di mulai dari tahun 2005-2009. Dari hasil perhitungan dengan teknik DEA diperoleh tabel efisiensi untuk masingmasing propinsi di pulau Jawa.

\section{Tabel 2}

Efisiensi pengelolaan keuangan propinsi di pulau Jawa (dalam \%)

\begin{tabular}{|l|c|c|c|c|c|}
\hline r. Propinsi & $\mathbf{2 0 0 5}$ & $\mathbf{2 0 0 6}$ & $\mathbf{2 0 0 7}$ & $\mathbf{2 0 0 8}$ & $\mathbf{2 0 0 9}$ \\
\hline DKI Jakarta & 54,68 & 57,92 & 71,32 & 100 & 100 \\
\hline Jawa Barat & 95,73 & 100 & 100 & 100 & 100 \\
\hline Jawa Tengah & 100 & 100 & 100 & 94,53 & 100 \\
\hline DTYogyakarta & 65,53 & 75,36 & 45,78 & 41 & 100 \\
\hline Jawa Timur & 100 & 100 & 100 & 100 & 100 \\
\hline Banten & 76,62 & 100 & 100 & 100 & 100 \\
\hline
\end{tabular}

Sumber: BPS diolah

Propinsi yang mampu mempertahankan tingkat efisiensinya selama lima tahun adalah propinsi Jawa Timur. Pada tahun 2005 Jawa Barat memiliki tingkat yang kurang efisien yaitu 95,73\%, dan Banten sebesar 76,62\%, namun pada tahun 2006-2009 Jawa Barat dan Banten dapat mencapai nilai efisien 100\%. Propinsi Jawa tengah dari tahun 2005-2007 dapat mempertahankan nilai efisien mencapai $100 \%$, akan tetapi pada tahun 2008 turun menjadi $94.53 \%$ dan pada tahun 2009 menjadi efisien lagi mencapai $100 \%$.

Propinsi Jawa timur memiliki sumberdaya alam yang potensial sehingga propinsi tersebut mempunyai modal untuk memperbaiki prekonomiannya yang dapat mensejahterakan kehidupan masyarakat. Jawa Timur sudah mempunyai surplus untuk membiayaai belanja rutinnya, hal ini dapat dilihat dari jumlah input yang dikeluarkan sama dengan jumlah output yang dihasilkan. Hal ini dikarenakan penggunaan kebijakan yang tepat sasaran sehingga dapat membantu pertumbuhan ekonominya.

Sedangkan propinsi yang tidak efisien adalah DI Yogyakarta sampai tahun 2008 hanya mencapai $41 \%$ dan pada tahun 2009 baru dapat mencapai tingkat efisiensinya, diikuti oleh propinsi DKI Jakarta dari tahun 2005-2007 kurang efisien tapi pada tahun 2008-2009 dapat mencapai $100 \%$. Propinsi yang efisiensinya kurang dari $100 \%$ memiliki inefisiensi di berbagai input yang digunakan dengan mempertahankan output yang sudah di hasilkan. 
Dari tabel 2 pada tahun 2005 dapat dilihat propinsi yang efisien (Efisien $=$ 100\%) adalah Propinsi Jawa Tengah dan Jawa Timur. Sedangkan propinsi yang tidak efisien (Efisien < 100\%) adalah DKI Jakarta, Jawa Barat, DI Yogyakarta dan Banten. Propinsi DKI Jakarta hanya mampu mencapai tingkat efisiensi sebesar $54,68 \%$, maka propinsi DKI Jakarta dapat mengurangi setiap inputnya sebesar $45,31 \%$ dengan mempertahankan tingkat output yang sudah dihasilkan. Masing-masing pengunaan nilai input yang sudah dikurangi pada propinsi DKI Jakarta ialah menggunakan Belanja Tidak Langsung sebesar Rp. 2.253.325.482 menggunakan Belanja Langsung sebesar Rp. 1.253.178.672, dan menggunakan sumber pengeluaran pemerintah sebesar Rp 1.618.522.584, dengan menggunakan input ini, maka Propinsi DKI Jakarta dapat menjadi efisien $100 \%$. Jadi selama ini Propinsi DKI Jakarta terlalu banyak mengeluarkan dana Belanja Tidak Langsung sebesar Rp. 1.867.078.786, Belanja Langsung sebesar Rp. 1.038.368.994 dan menggunakan sumber pengeluaran pemerintah sebesar Rp. 1.341.088.599. Jadi sumber-sumber inefisiensi dari Propinsi DKI Jakarta dan propinsi-propinsi yang tidak efisien yang lainnya terdapat pada tingkat penggunaan input yang harus dikurangi atau terjadi pemborosan.

Dari tabel 2 pada tahun 2006 propinsi yang paling rendah efisiensinya yaitu masih propinsi DKI Jakarta yang hanya mampu mencapai tingkat efisiensi sebesar 57,92\%, maka propinsi DKI Jakarta bisa menjadi efisien dengan mengurangi setiap inputnya sebesar $42,07 \%$ dengan mempertahankan tingkat output yang sudah dihasilkan. Masing-masing pengunaan nilai input yang sudah dikurangi pada propinsi DKI Jakarta adalah dapat menggunakan Belanja Tidak Langsung sebesar Rp. 2.989.470.268 mengunakan Belanja Langsung sebesar Rp. 3.306.755.472 dan menggunakan sumber pengeluaran daerah sebesar Rp. 1.322.400.335 dengan menggunakan input ini, maka Propinsi DKI Jakarta dapat mencapai tingkat efisiensi $100 \%$.

Pertumbuhan tersebut tidak terlepas oleh pengaruh negatif masih belum pulihnya prekonomian dunia. Dari sisi permintaan, perlambatan lebih disebabkan oleh melemahnya ekspor dan terbatasnya investasi, sementara konsumsi diperkirakan masih tetap tinggi. Dari sisi penawaran, sebagian besar sektor yang terkait dengan ekspor mengalami perlambatan, sementara sektor yang terkait dengan konsumsi diperkirakan perlambatannya tertahan. (Bapeda DKI Jakarta, 2009).

Penyebab lain terjadinya inefisiensi di propinsi DKI Jakarta adalah jumlah input yang dikeluarkan tidak sesuai dengan jumlah output yang dihasilkan. Diantaranya dalam sektor tenaga kerja, di propinsi DKI Jakarta banyak industriindustri besar sehingga banyak lapangan kerja yang tersdia, dengan kondisi ekonomi seperti itu menyebabkan banyak orang yang beranggapan bahwa 
kota Jakarta dapat merubah ekonomi seseorang menjadi lebih baik. Hal ini menyebabkan orang yang mencari pekerjaan lebih banyak dibandingkan dengan lapangan kerja yang tersedia.

Dari tabel 2 pada tahun 2007 propinsi yang paling rendah efisiensinya adalah Propinsi DI Yogyakarta yang hanya mampu mencapai tingkat efisiensi sebesar 45,78\%, maka Propinsi DI Yogyakarta bisa menjadi efisien dengan mengurangi setiap inputnya sebesar $54,22 \%$ dengan mempertahankan tingkat output yang sudah dihasilkan. Masing-masing penggunaan nilai input yang sudah dikurangi pada Propinsi DI Yogyakarta ialah dapat menggunakan Belanja Tidak Langsung sebesar Rp. 269.240.268, Belanja Langsung sebesar Rp. 162.390.236, dan dapat menggunakan Sumber Pengeluaran daerah sebesar Rp. 102.638.331, dengan digunakannya input ini, maka Propinsi DI Yogyakarta dapat menjadi efisien $100 \%$.

Dari tabel 2 pada tahun 2008 propinsi yang paling rendah efisinsinya yaitu masih Propinsi DI Yogyakarta yang hanya mampu mencapai tingkat efisiensi 41,04\%, maka Propinsi DI Yogyakarta bisa menjadi efisien dengan mengurangi setiap inputnya sebesar 58,96\% dengan mempertahankan tingkat output yang sudah dihasilkan. Masing-masing penggunaan nilai input yang sudah dikurangi pada Propinsi DI Yogyakarta ialah dapat menggunakan Belanja Tidak Langsung sebesar Rp. 810.552.991, Belanja Langsung sebesar Rp. 623.739.440, dan dapat menggunakan Sumber Pengeluaran Daerah sebesar Rp. 239.419.668, dengan digunakannya input ini maka Propinsi DI Yogyakarta dapat mencapai tingkat efisiensi $100 \%$.

Pada tahun 2009 seluruh propinsi yang ada di Pulau Jawa dapat mencapai efisiensi $100 \%$ dengan menggunakan tingkat input dan output yang sudah digunakan. Sedangkan bagi propinsi-propinsi pada tahun-tahun sebelumnya yang belum mencapai tingakat efisiensi $100 \%$, agar propinsi-propinsi tersebut menjadi efisien dapat menggunakan input-input yang terdapat di dalam tabel 3, dan tabel ini juga menjelaskan pemborosan yang terjadi pada propinsi yang tidak efisien. 


\section{Tabel 3}

Penggunaan Input yang Efisien pada Tingkat Output yang Dihasilkan dan Pemborosan (Dalam Rupiah)

\begin{tabular}{|c|c|c|c|c|c|c|c|}
\hline \multirow{2}{*}{ 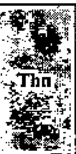 } & \multirow{2}{*}{ 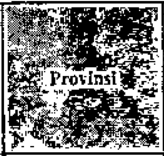 } & \multicolumn{3}{|c|}{ F } & \multicolumn{3}{|c|}{ Pemborosad y } \\
\hline & & 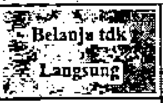 & Bclsofa & $\begin{array}{l}\text { Pecgleran } \\
\text { Derah } \\
\text { Derat }\end{array}$ & $\begin{array}{l}\text { Belanjatds } \\
\text { Langsugg: }\end{array}$ & $\begin{array}{l}\text { Belajia: } \\
\text { Langung } \\
\end{array}$ & $\begin{array}{c}\text { Penglaran } \\
\text { Daerab }\end{array}$ \\
\hline \multirow[t]{4}{*}{2005} & DKI Jakarta & 2.253325 .481 & 1.253 .178 .671 & 1.618522 .583 & 1.867 .606 .269 & 1.038 .662351 & 1.341.467.510 \\
\hline & Jawa Barat & 1.853 .542 .704 & 1.030 .840 .951 & 1.331 .365 .908 & $82.676 .562,69$ & $45.980 .265,96$ & $59.385 .066,62$ \\
\hline & DI Yogyakarta & 201.786 .024 & 127.857 .090 & 129.023 .011 & $106.143 .205,4$ & $67.255 .209,71$ & $67.868 .505,86$ \\
\hline & Banten & 443.436 .640 & 246.615 .654 & 318.512 .448 & $135.311 .258,7$ & $75.252 .858,14$ & $97.191 .608,38$ \\
\hline \multirow[t]{2}{*}{2006} & DKJ Jakarta & 2.989 .470 .268 & 3.306 .755 .472 & 1.322 .400 .335 & 2.171 .907 .957 & 2.402 .421 .793 & $960.749 .414,7$ \\
\hline & D1 Yogyakarla & 248.661 .230 & 179.595 .085 & 1.011 .104 .316 & $81.303 .247,18$ & $58.721 .110,59$ & $330.594 .617,1$ \\
\hline \multirow[t]{2}{*}{2007} & DKI Jakarta & $4,404,327.875$ & 3.910 .217 .877 & 1.311 .527 .769 & 1.771 .117 .827 & 1.572 .420 .762 & $527.406 .287,4$ \\
\hline & DI Yogyakerta & 269.240 .268 & 162.390 .236 & 102.638 .331 & $227.329 .757,8$ & 137.312 .228 & $86.661,431,08$ \\
\hline \multirow[t]{2}{*}{2008} & Jawa Tengah & 15.014 .912 .096 & 9.539 .227 .396 & 3303.785 .418 & $868.841 .311,4$ & $551.989 .567,9$ & $191.174 .296,4$ \\
\hline & DI Yogyaikarta & 810.552 .991 & 623.739 .440 & 239.419 .668 & $563.265 .637,8$ & 433.446.051,5 & $166.376379,5$ \\
\hline
\end{tabular}

Sumber : BPS diolah

Pemborosan yang dimaksud tabel di atas adalah bahwa beberapa propinsi dengan menggunakan input yang besar hanya mampu menghasilkan output yang kecil atau tidak maksimal, input yang digunakan tidak terlalu mempengaruhi tingkat output yang dihasilkan sehinga menjadi tidak efisien. Dari perhitungan DEA juga dapat dilihat bahwa propinsi-propinsi yang tidak efisien mempunyai nilai efficient reference set atau adanya propinsi-propinsi lain yang dapat dijadikan sebagai acuan atau Benchmark dalam meningkatkan tingkat efisiensinya. Berikut ini adalah ringkasan dari objective function value (efisiensi), efficient reference set dan multiplier dari seluruh propinsi di Pulau Jawa tahun 2005-2008 untuk tabel input yang tidak efisien. 


\section{Tabel 4}

Multiplier, Efisiensi dan Efficient Reference Set dari Seluruh Propinsi di

Pulau Jawa yang Tidak Efisien tahun 2005-2008

\begin{tabular}{|c|c|c|c|c|}
\hline Tahun & Wropinsi & Effiviensi $(\%)$ & 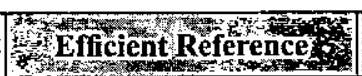 & Multiplier, \\
\hline \multirow{4}{*}{2005} & DKI Jakarta & 54,68 & Jawa Timur & 1,151 \\
\hline & Jawa Barat & 95,73 & Jawa Timur & 0,947 \\
\hline & DI Yogyakarta & 65,53 & $\begin{array}{c}\text { Jawa Tengah } \\
\text { Jawa Timur }\end{array}$ & $\begin{array}{l}0,104 \\
0,008\end{array}$ \\
\hline & Banten & 76,62 & Jawa Timur & 0,227 \\
\hline \multirow{2}{*}{2006} & DKI Jakarta & 57,92 & $\begin{array}{l}\text { Jawa Timur } \\
\text { Banten }\end{array}$ & $\begin{array}{l}1,020 \\
0,588 \\
\end{array}$ \\
\hline & DI Yogyakarta & 75,36 & $\begin{array}{l}\text { Jawa Barat } \\
\text { Jawa Tengah }\end{array}$ & $\begin{array}{l}0,005 \\
0,107\end{array}$ \\
\hline \multirow{2}{*}{2007} & DKI Jakarta & 71,32 & $\begin{array}{l}\text { Jawa Timur } \\
\text { Banten }\end{array}$ & $\begin{array}{l}0,415 \\
3,281\end{array}$ \\
\hline & DI Yogyakarta & 45,78 & $\begin{array}{l}\text { Jawa Tengah } \\
\text { Jawa Timur }\end{array}$ & $\begin{array}{l}0,098 \\
0,009\end{array}$ \\
\hline \multirow[b]{2}{*}{2008} & Jawa Tengah & 94,53 & Jawa Barat & 0,938 \\
\hline & DI Yogyakarta & 41 & $\begin{array}{c}\text { DKI Jakarta } \\
\text { Jawa Barat }\end{array}$ & $\begin{array}{l}0,019 \\
0,043\end{array}$ \\
\hline
\end{tabular}

Sumber: BPS diolah

Dari tabel di atas dapat dilihat bahawa propinsi-propinsi yang tingkat input dan outputnya tidak efisien dapat mengacu pada efficient reference set, sehingga dapat di tentukan input dan output propinsi yang efisien untuk propinsi yang tidak efisien.

Dari tabel 4 di atas, pada tahun 2005 besarnya tingkat efisiensi propinsi DKI Jakarta adalah sebesar $54,68 \%$, dengan benchmark atau propinsi yang dijadikan sebagai acuan adalah propinsi Jawa Timur yang mempunyai nilai multiplier 1,151 , Multiplier tersebut berfungsi sebagai angka pengganda yang dinamis sebagai dasar untuk menyesuaikan input dan output di propinsi DKI Jakarta agar menjadi efisien. Dari hasil pengolahan data menggunakan DEA propinsi DKI Jakarta untuk menjadi efisien jika dibandingkan dengan propinsi Jawa Timur, maka dapat menggunakan Belanja tidak langsung sebesar Rp. 2.955.091.871, menggunakan Belanja Langsung Rp. 1.252.732.748, dan menggunakan Surnber Pengeluaran Daerah sebesar Rp. 1.617.946.658. Dengan menggunakan masingmasing input yang telah dikurangi maka Propinsi DKI Jakarta dapat mencapai tingkat efisiensi $100 \%$. 
Pada tahun 2006 Propinsi DKI Jakarta masih tidak efisien, walaupun mengalami kenaikan dari tahun sebelumnya tapi hanya mencapai tingkat efisiensi $57,92 \%$ dengan Benchmark atau propinsi yang dijadikan sebagai acuan adalah 'Propinsi Jawa Timur dan Banten, yang mempunyai nilai Multiplier sebesar 1,020 dan 0,588. Multiplier tersebut berfungsi sebagai angka pengganda yang dinamis sebagai dasar untuk menyesuaikan input dan output di Propinsi DKI Jakarta agar menjadi efisien. Dari hasil pengolahan data menggunakan DEA Propinsi DKI Jakarta untuk menjadi efisien jika dibandingkan dengan Propinsi Jawa Timur dan Banten maka dapat menggunakan Belanja Tidak Langsung sebesar Rp. 2.988.703.389, menggunakan Belanja Langsung sebesar Rp. 3.305.900.944 dan menggunakan Sumber Pengeluaran Daerah sebesar Rp. 1.322.034.023. Dengan menggunakan masing-masing input yang telah dikurangi maka Propinsi DKI Jakarta dapat mencapai tingkat efisiensi $100 \%$.

Propinsi DKI Jakarta perlu menentukan arah pembangunannya dalam jangka menengah hingga jangka panjangyang masing-masing dituangkan ke dalam RPJM (Rencana Pembangunan Jangka Menegah) dan RPJP (Rencana Pembangunan Jangka Panjang) daerah. Prioritas-prioritas pembangunan dalam RPJM dan RPJP inilah yang akan menentukan pola alokasi belanja di daerah 'di samping juga sumber-sumber pembiayaannya yang ideal. Khusus untuk propinsi DKI Jakarta, visi jangka panjang propinsi DKI Jakarta adalah menjadi Service City di Indonesia. Visi ini tentunya harus diinterpretasikan secara baik dalam RPJM maupun RPJP DKI Jakarta. Untuk menjadikan Jakarta sebagai service city, pembenahaan tata ruang serta pembangunan infrastruktur dan SDM 'di DKI Jakarta sangatlah perlu mendapatkan penanganan yang lebih serius. Di lain pihak, ruang gerak anggaran daerah perlu lebih dioptimalkan. Hal ini bisa ditempuh tidak hanya melalui mobilisasi sumber pendapatan yang ada, tetapi juga melalui upaya lainnya seperti penggalian sumber pembiayaan dari pinjaman dan obligasi daerah, efisiensi belanja daerah, penganggaran partisipatif yang melibatkan peran masyarakat, serta pengupayaan public-private partnership di dalam pembangunan infrastruktur di wilayah DKI Jakarta.

Melihat perkembangan pembangunan di propinsi DKI Jakarta, diperlukan paradigma peningkatan penerimaan asli daerah yang sekaligus juga dapat mendorong investasi. Peranan investasi swasta menjadi penting untuk memenuhi kebutuhan pertumbuhan ekonomi daerah yang tinggi. Hal ini bisa dilihat pada target pertumbuhan ekonomi yang tinggi selama lima tahun ke depan yaitu 7 8\%. (Bapeda DKI Jakarta, 2009).

Pada tahun 2007 DI Yogyakarta hanya mencapai tingkat efisien sebesar $45,78 \%$ propinsi yang dijadikan sebagai acuan atau Benchmark adalah propinsi Jawa Tengah dan Jawa Timur, yang mempunyai nilai Multiplier sebesar 0,098 
dan 0,009. Multiplier tersebut berfungsi sebagai angka pengganda yang dinamis sebagai dasar untuk menyesuaikan input dan output di Propinsi DI Yogyakarta agar menjadi efisien. Dari hasil pengolahan data menggunakan DEA Propinsi DI Yogyakarta untuk menjadi efisien jika dibandingkan dengan Propinsi Jawa Tengah dan Jawa Timur maka dapat menggunakan Belanja Tidak Langsung sebesar Rp. 4.145.705.954, Belanja Langsung sebesar Rp. 3.909.377.630 dan menggunakan Sumber Pengeluaran Daerah sebesar Rp. 1.310.922.822, Dengan menggunakan masing-masing input yang telah dikurangi maka Propinsi DI Yogyakarta dapat mencapai tingkat efisien $100 \%$.

Pada tahun 2008 Propinsi DI Yogyakarta tingkat efisiensinya turun menjadi 41\%, dengan Propinsi sebagai acuan atau Benchmark adalah Propinsi DKI Jakarta dan Jawa Barat, dengan nilai Multiplier sebesar 0,019 dan 0,043. Multiplier tersebut berfungsi sebagai angka pengganda yang dinamis sebagai dasar untuk menyesuaikan input dan output di Propinsi DI Yogyakarta agar menjadi efisien. Dari hasil pengeolahan -data menggunakan analisis DEA, Propinsi DI Yogyakarta agar menjadi efisien jika dibandingkan dengan Propinsi DKI Jakarta dan Jawa Barat maka dapat menggunakan Belanja Tidak Langsung sebesar Rp. 805.912.489, Belanja Langsung sebesar Rp. 622.510.296, dan menggunakan Sumber Pengeluaran Daerah sebesar Rp. 239.363.688. Dengan menggunakan masing-masing input yang telah dikurangi, maka Propinsi DI Yogyakarta dapat mencapai tingkat efisien $100 \%$.

Tabel 5

Penggunaan Input yang Efisien pada Tingkat Output yang Dihasilkan dengan Perbandingan Propinsi yang Efisien (benchmark)

(Dalam Ribuan)

\begin{tabular}{|c|c|c|c|c|}
\hline Tahun & Propinsi & $\begin{array}{l}\text { Belanja Tdk } \\
\text { Latakg } \\
\text { Langsung }\end{array}$ & $\begin{array}{l}\text { Belanja } \\
\text { Langsung } \\
\text { Leang }\end{array}$ & $\begin{array}{l}\text { Sumber } \\
\text { Pengeluarandararah }\end{array}$ \\
\hline \multirow{4}{*}{2005} & DKI Jakarta & 2.955 .091 .871 & 1.252 .732 .748 & 1.617 .946 .658 \\
\hline & Jawa Barat & 1.853 .292 .716 & 1.030 .701 .922 & 1.331 .186 .347 \\
\hline & DIY & $201.857 .103,5$ & $127.882 .428,2$ & $129.088 .514,1$ \\
\hline & Banten & $44.424 .228,7$ & 247.063 .713 & $319.091,130,6$ \\
\hline \multirow{2}{*}{2006} & DKI Jakarta & 2.988 .703 .389 & 3.305 .900 .944 & 1.322 .034 .023 \\
\hline & DIY & $246.995 .307,3$ & $25.368 .101,6$ & $100.466 .696,3$ \\
\hline \multirow{2}{*}{2007} & DKI Jakarta & 4.145 .705 .954 & 3.909 .377 .630 & 1.310 .922 .822 \\
\hline & DIY & $268.004 .034,4$ & $155.752 .154,8$ & $102.038 .799,1$ \\
\hline \multirow{2}{*}{2008} & Jawa Tengah & 15.010 .011 .000 & 9.536 .113 .694 & 3.302 .707 .030 \\
\hline & DIY & $805.912 .489,6$ & $622.510 .296,3$ & $239.363 .688,2$ \\
\hline
\end{tabular}

Sumber: BPS diolah 
Propinsi yang selama 5 tahun tingkat efisiensinya naik turun adalah Propinsi DI Yogyakarta. Pada tahun 2005 hanya mencapai tingkat efisiensi sebesar $65,53 \%$, tahun 2006 naik menjadi sebesar 75,36, pada tahun 2007 turun menjadi sebesar 54,78\%, tahun 2008 mengalami penurunan lagi menjadi sebesar $41 \%$.Salah satu penyebab terjadinya inefisensi dikarenakañ Đi Yogyakarta merupakan kota pendidikan, banyak pendatang yang masuk untuk menuntut ilmu, sehingga pemerintah DI Yogyakarta harus menyediakan sarana dan prasarana untuk kebutuhan masyarakat di propinsi tersebut seperti penyediaan dan perbaikan jalan raya, dan belanja lainnya yang sejenis. Sedangkan banyak pendatang yang membawa kendaraan dari daerah asalnya sehingga pajak kendaraannya tetap masuk ke daerahnya masing-masing, sementara DI Yogyakarta harus tetap mengeluarkan biaya sarana dan prasarana tanpa ada pemasukan yang seimbang.

Rendahnya kesempatan kerja dikarenakan DI Yogyakarta tidak memiliki industri besar, sehingga tenaga kerja yang dibutuhkan yang memiliki kualifikasi tertentu seperti bekerja sebagai dosen harus menempuh S2 hal ini menyebabkan orang-orang yang pendidikannya dibawah S1 tidak mempunyai. banyak kesempatan untuk bekerja.

Pada tahun 2009 DI Yogyakarta dapat mencapai tingkat efisiensi $100 \%$, menigkatnya pertumbuhan ekonomi dikarenakan pemerintahan DI Yogyakarta mampu menyusun rencana untuk memperbaiki prekonomiannya diantaranya:

a. Peningkatan Penerimaan Daerah, khususnya Pendapatan Aśli Daerah, dengan cara meningkatkan kesadaran masyarakat dalam bidang pendapatan asli daerah

b. Peningkatan efisiensi dan efektivitas pada sisi pengeluaran, dengan penataan bidang perencanaan, pelaporan dan evaluasi pendapatan

c. Peningkatan kemitraan antara Pemerinatah Daerah dan Swasta khususnya dalam penyediaan infrastruktur

d. Pendirian dan pengembangan BUMD sebagai alternatif penguatan Keuangan Daerah.

Dengan strategi ini, kemampuan daerah dalam menyediakan fasilitas pelayanan umum dan infrastruktur lainnya diharapkan akan meningkat. Hasil akhirnya pemerintah daerah akan dapat menarik investasi dan perusahaanperusahaan baik dari dalam maupun luar negeri yang berdampak terhadap peningkatan kemakmuran masyarakat dan mempertajam daya saing daerah. (Lela Dina Pertiwi, 2007). 


\section{Kesimpulan Dan Implikasi Kebijakan}

\section{Kesimpulan}

Penelitian ini hanya menyoroti dari sisi input sehingga sumber inefisiensi atau pemborosan terdapat pada input dengan tingkat output yang sudah dihasilkan dan dipertahankan. Sumber-sumber inefisiensi terdapat pada Belanja Tidak Langsung, Belanja Langsung dan Sumber Pengeluaran Daerah. Terjadinya inefisiensi dikarenakan penggunaan input tersebut terlalu besar atau tidak sesuai dengan pencapaian output yang dihasilkan. Jadi apabila propinsi yang memiliki nilai inefisien atau $<100 \%$, maka solusinya propinsi tersebut harus mengurangi penggunaan jumlah inputnya dengan tetap mempertahankan jumlah output yang sudah dihasilkan, atau dapat mengunakan tingkat input yang sama tetapi dibarengi dengan peningkatan jumlah output yang lebih besar, hal ini dapat dilakukan dengan cara pengalokasian dana tersebut ke sektor yang dapat mempengaruhi kenaikan output tersebut.

\section{Implikasi}

Propinsi yang sudah mencapai tingkat efisiensi $100 \%$, diharapkan dapat mempertahankannya, sedangkan bagi propinsi-propinsi yang tingkat efisiensinya masih kurang dari $100 \%$ diharapkan dapat lebih selektif dan berhati-hati dalam penggunaan inputnya agar dapat mendapatkan output yang sesuai dan maksimal. Setiap propinsi di pulau Jawa mempunyai kekayaan sumber daya yang perbedaannya tidak terlalu signifikan, dan masih bisa diimbangi dengan penggunaan input yang dimillki oleh tiap-tiap propinsi. Jika dibandingkan antara propinsi yang efisien dengan propinsi yang tidak efisien yaitu Jawa Timur Dan DI Jogyakarta dilihat dari jumlah Belanja Tidak Langsung, Belanja Langsung dan Sumber Pengeluaran Daerah jumlahnya cukup jauh, salah satunya hal ini dipengaruhi oleh letak Geografis dan kekayaan alam yang berbeda sehingga menimbulkan banyak perbedaan dalam kehidupan ekonomi, sosial dan budaya. Namun perbedaan ini bukan merupakan sebuah hambatan untuk sama-sama berkembang karena bagi propinsi yang belum efisien dapat terus memperbaiki penggunaan input yang dimiliki untuk mendapatkan output yang maksimal. Selain itu, Perlunya monitoring dan evaluasi terhadap pengelolaan keuangan pemerintah daerah dari pihak pemerintah pusat agar dapat mengurangi pemborosan dan dapat menyusun rencana untuk menggunakan dana untuk sektor yang tepat sasaran sesuai dengan kebutuhan. 


\section{DAFTAR PUSTAKA}

Baro, Robert J, 1991, Economic Growth in A Cross Section of Countries, Quartely

Journal of Economic. 105 (2), p. 501-526.

Bapeda DKI Jakarta, 2009, “Arah Kebijakan Keuangan Daerah" Jurnal Ekonomi

Pembangunan. 60-61.

Basuki, S.H. (2008), Pengelolaan Keuangan Daerah, Kreasi Wacana.

Bennet, R.J. (1980) The Geography of Public Finance: “ Welfare under fiskal

Federalisme and Local Goverment Finance". Methuen, London

Brown, C.V. and Jackson, P.M. (1990), Public Sector Economics, Blackwell, Oxford

Budi Sampurna, 2011, "Menengok Kembali Isu Efisiensi Dalam Praktik Desentralisasi" www. Artikel Efisiensi \& Tiebout.htm

Daniel M' Amanja and Oliver Morriessey, 2006, Fiscal Policy and Economic Growth in Kenya, Credit Research Paper, Center for Research in Economi Development and Internasional Trade, University of Nottingham.

Ding, Ying(2002), Fiscal Desentralization and Economic Growth in China, 19942002, Fublic Finance and Sosial Security I, Osaka University, JAPAN

Greiner, Alfred, 1996, "Fiscal Policy in a Model of Endegenpus Growth mith Lerning by Doing" Public Finance Quarterly, vol.24, p.371-397.

Helms, L, 1985, "The Effect of State and Local Taxes on Economics Growth: a

Time Series- Cross Section Approach", Review of Economics \& Statistics, 67, p:574-582.

Jorge Martinez-Vazquez \& Robert M McNab, 1997, Fiscal Decentralization, Economic Growth and Democratic Governance, Economic Departemen and Policy Research Center Georgia State University.

Kim, Sung Tai, 1997, " The Role of Local Public Sectors ini Regional Ekonomic Growth In Korea", Asian Economic Journal 1997, vol 11, No. 21, p. 155168.

Lela Dina Pertiwi, 2007, “ Efisiensi Pengeluaran Pemerintah Daerah di DI Yogyakarta" Jurnal Ekonomi Pembangunan, 123-129.

Martinez, Jorge, Vazquez, 2001, Fiscal Decentralization and Economic Growth, $J E L$ Classifications, E62, H77.

Nijkamp, P. and Poot J (2002), Meta Analysis of The Impact of Fiscal Policies on Long Run Growth, Tinbergen Institute Discussion Paper, TI 2002 Rahayu, Siti Aisyah T, 2000, Peranan Sector Public Local terhadap Pertumbuhan Ekonomi Regional di Indonesian, tesis, tidak dipublikasikan.

Smoke, P.J. (1994) Local Government Finance in Developming Countries: The Case of Kenya, Oxford University Press, Oxford 